\title{
Characterization of Edible Pork By-products by Means of Yield and Nutritional Composition
}

\author{
Pil Nam Seong*, Kuyng Mi Park, Soo Hyun Cho, Sun Moon Kang, Geun Ho Kang, \\ Beom Young Park, Sung Sil Moon ${ }^{1}$, and Hoa Van Ba \\ Animal Products and Processing Division, National Institute of Animal Science, Suwon 441-706, Korea \\ ${ }^{1}$ Sunjin Meat Research Center, Seoul 134-822, Korea
}

\begin{abstract}
Basic information regarding the yield and nutritional composition of edible pork by-products, namely heart, liver, lung, stomach, spleen, uterus, pancreas, and small and large intestines, was studied. Our results revealed that the yields varied widely among the pork by-products examined; in particular, liver had the highest yield (1.35\%); whereas, spleen had the lowest yield $(0.16 \%)$. The approximate composition range (minimum to maximum) of these by-products was found to be: moisture 71.59-82.48\%; fat 0.28-19.54\%; ash 0.155-1.34\%, and protein 8.45-22.05\%. The highest protein, vitamin A, B2, B6, and total essential amino acid (EAA) contents were found in liver. Large intestine had the highest fat content and lowest EAA content. Heart had the highest vitamin B1 content, whereas pancreas had the highest niacin and vitamin B3 contents. The concentrations of $\mathrm{Fe}$ and $\mathrm{Zn}$ were highest in liver and pancreas. Total saturated fatty acids (SFA) levels and polyunsaturated fatty acids (PUFA) levels between the by-products ranged from 43.15-50.48\%, and 14.92-30.16\%, respectively. Furthermore, with the exception of large intestine, all the by-products showed favorable PUFA/SFA ratios. The study indicated that almost all of the pork by-products examined were good sources of important nutrients, and that these data will be of great importance in the promotion of the consumption of edible pork by-products, as well as their utilization in meat processing.
\end{abstract}

Keywords: pork by-product, mineral, vitamin, amino acid, fatty acid

\section{Introduction}

The edible meat by-products comprise a variety of products including internal organs (e.g., heart, lung, liver, spleen and kidney), entrails and other parts such as head, tail and feet etc. These edible by-products constitute a significant ratio of live weight of an animal, and the yields of these by-products varies depending upon the animal species, ranging from $10-30 \%$ of the live weight of pig and cattle, respectively (Ockerman and Basu, 2004). The world meat consumption has increased in recent years which means that large quantity of edible meat byproducts are produced every day from slaughterhouses while the utilization of these by-products for human consumption has declined (Ockerman and Basu, 2004). The

\footnotetext{
*Corresponding author: Pil Nam Seong, Animal Products and Processing Division, National Institute of Animal Science, Suwon 441-706, Korea. Tel: +82-31-290-1699, Fax: +82-31-2901697, E-mail: bacbun1981@gmail.com
}

large amount of meat by-products has become a burden to the slaughterhouses in disposing of theme when they are not utilized (Toldra et al., 2012). However, this abundant available source also produces good opportunities for the meat industry and processors in utilization of these raw materials to increase economic profitability concurrently reduce the loss of this valuable source of revenue.

The utilization of the meat by-products considerably depends upon a number of factors such as; culture, religion, earnings and preference etc. In general, however the edible meat by-products are widely used in many countries worldwide in different traditional dishes for instance; sheep liver (Iran), boiled tongue (South America), pork's feet and pork's ears (Spain), sundae dish (Korea) and so on (Toldra et al., 2012). Especially, all parts of edible meat by-products are salvaged and commonly used as human foods in South Africa, Egypt, Italia, Spain and Asian countries etc (Nollet and Toldra, 2011). On the other hand, the consumption of edible meat by-products also varies depending on animal species for instance; the edible meat 
by-products of goat is more commonly consumed than cattle's edible offal in some countries such as Indonesia, India, Pakistan and Bangladesh; while the offal of chicken is most commonly consumed in Japan (Nollet and Toldra, 2011).

More to the point, efficient utilization of edible meat by-products is important in order to support economical and viable meat production systems (Kurt and Zorba, 2007). In fact, some attempts have been made aiming to increase the commercial values of edible meat by-products by using them in various meat products such as liver pate, liver sausage, and blood sausage (Estevez et al., 2005; Nollet and Toldra, 2011; Santos et al., 2003). However, the utilized quantity of the meat by-products is still much lesser compared with their large amount generated.

Calculating only in South Korea, approximately millions of pigs are slaughtered per year (Agriculture and Horticulture Development Board, 2013), implying that a considerable amount of meat by-products is generated every day from the slaughterhouses. It can be stated that about hundreds of tons of edible pork by-products are produced per year in the country. Although the edible pork by-products are widely consumed in Korea, these by-products generally have a low commercial value and the consumption of these products is limited. This is probably due to the lack of scientific information to consumers about the nutritional composition of these pork by-products. Therefore, awareness of the nutritive values of the pork meat by-products is important that may help to promote the consumption (amount and scope) and their future utilization.

For the past decades, studies have only focused on muscle meats from animal species; a great amount of scientific information (e.g., physicochemical composition, quality attributes, sensory and their utilization etc.) about the muscle meats is available on internet and textbooks etc. Whereas, the edible meat by-products are also widely used for human foods however the scientific information regarding the nutritional quality of these meat by-products is scarce with limited data available. While edible meat by-products from pork origin account for a significant ratio of live weight and these all by-products are widely consumed, relatively limited scientific information on the nutritional quality of pork by-products is available. Therefore, the objective of the present study was to investigate the yield and nutritional composition of majority of pork by-products. The findings of our study would be beneficial for promoting consumption and future utilization of edible pork by-products.

\section{Materials and Methods}

\section{Sample preparation}

Landrace $\times$ Yorkshire $\times$ Duroc $($ LYD) crossbred pigs at 6 mon of age with their live weights of about $130-140 \mathrm{~kg}$ were obtained from the Rural Development Administration Institute (RDA), Suwon, South Korea. Before harvesting, the animals were reared in different pens and fed with a commercial diet. The animals were transported to an abattoir of the of National Institute of Animal Science, Suwon, South Korea, where the animals were slaughtered. After slaughter, their offal samples were immediately collected and used for the present investigation. The selected offal samples (heart, liver, lung, stomach, small intestine, large intestine, spleen, uterus and pancreas) were washed under running tap water to remove adhering blood, food remnants, feces, trimmed off of visible fats and connective tissues. After draining the water, the offal samples were weighed to determine yield, and were then stored at $2-4^{\circ} \mathrm{C}$ and used for analyses of proximate and nutritional compositions. Each offal sample was analyzed in triplicates.

\section{Proximate composition and calorie}

Moisture, protein, fat and ash contents of offal samples were analyzed according to the method of the Association of Official Analytical Chemists (AOAC, 2000). Particularly, the moisture and fat contents were determined by using a moisture \& fat analyzer (SMART Trac, CEM Corp., USA); nitrogen content was determined by using a nitrogen analyzer (Rapid N cube, Elementar, Germany) and then converted into protein content using the $\mathrm{N} \times 6.25$ equation $(\mathrm{N}=$ nitrogen content obtained from the samples, and $6.25=$ conversion factor); and ash content was determined by using a microwave ashing oven (MAS 7000, CEM Corp., USA). To determine calorie, the offal sample (50 g each) was homogenized in a blender (HMF 3160S, Hanil Co., Korea), then the homogenized sample was used for measurement of calorie content by using a caloriemeter model 1261 (Parr instrument, USA). Calories were expressed as cal/g of the sample.

\section{Vitamin content}

Vitamins (vitamin A, B1, B2, niacin, B5 and B6) in the pork by-products were determined by following the procedures of AOAC (2000) using a reversed-phase high performance liquid chromatography (RP-HPLC) (Aglient 1200 series, Aglient, USA). 


\section{Amino acid content}

Samples used for amino acid analysis were hydrolyzed with $6 \mathrm{~N} \mathrm{HCl}$ solution for $24 \mathrm{~h}$ at $110^{\circ} \mathrm{C}$. The hydrolyzed samples were concentrated at $50^{\circ} \mathrm{C}$ and then diluted with $50 \mathrm{~mL}$ of $0.2 \mathrm{~N}$ sodium citrate buffer ( $\mathrm{pH} 2.2$ ), and finally the samples were filtered through $0.45 \mu \mathrm{m}$ filters (Millipore Corp., USA). The amino acids were determined by applying the filtrates ( $30 \mu \mathrm{L}$ each) to an amino acid analyzer (model 8900A) equipped with an exchange column $(4.6 \times 60 \mathrm{~mm})$ (Hitachi, Japan). The separation and detection of amino acids were carried out using the method as described by Spackman et al. (1958).

\section{Mineral content}

Mineral content of the samples was determined by following the method of AOAC (2000). Briefly, five grams of each sample was destroyed by dry ashing in a microwave ashing oven (MAS 7000, CEM Corp., USA) for 12 $\mathrm{h}$ with a final temperature of $600^{\circ} \mathrm{C}$. The ash content was dissolved in $10 \mathrm{~mL}$ of $37 \% \mathrm{HCl}$ and distilled water $(1: 1$ $\mathrm{v} / \mathrm{v})$ solution and was then filtered through Whatman filter paper (No. 6) (AEC Scientific Co., Korea). Minerals including $\mathrm{Na}$ (selected wavelength $588.9 \mathrm{~nm}), \mathrm{K}$ (766.5 $\mathrm{nm}), \mathrm{Ca}$ (422.7 nm), Mg (285 nm), P (470 nm), Fe (248.3 $\mathrm{nm})$, and $\mathrm{Zn}(213.9 \mathrm{~nm}), \mathrm{Mn}(279.5 \mathrm{~nm}), \mathrm{Cu}(324.7 \mathrm{~nm})$ and $\mathrm{Cr}(357.9 \mathrm{~nm})$ were determined by atomic emission spectrophotometer ICP-OES (Spectro, Boschstr, Germany). A calibration curve was prepared for each element.

\section{Fatty acid composition}

Fatty acid composition was extracted according to the methods of Folch et al. (1957) and Morrison and Smith (1964). The fatty acids were analyzed using a gas chromatograph system (Varian star 3600, Varian Inc., USA) equipped with flame ionization detector and Omegawax 205 fused-silica bond capillary column $(30 \mathrm{~m} \times 0.32 \mathrm{~mm}$ $\times 0.25 \mu \mathrm{m}$ film thickness). The initial and final temperature of the oven were $140^{\circ} \mathrm{C}$ and $230^{\circ} \mathrm{C}$, respectively. The injector port and detector temperatures were $250^{\circ} \mathrm{C}$ and $260^{\circ} \mathrm{C}$ respectively. The fatty acid profile was expressed as percentages of individual fatty acids identified.

\section{Statistical analysis}

The data were collected using Microsoft Office Excel 2007 and subjected to statistic analysis using the Statistic Analysis System (SAS) package (2007). The pooled data were analyzed using the General Linear Models (GLM) of the SAS program. Significant differences among pork by-products were analyzed by Duncan's Multiple Range test at $p<0.05$.

\section{Results and Discussion}

\section{Yield of pork by-products}

Yields of nine selected pork by-products are shown in Table 1. The yields showed a large variation between the by-products determined. Liver had the highest yield $(1.35 \%)$ whereas the spleen had the lowest yield $(0.16 \%)$. Small and large intestines had similar yield values $(0.86 \%$ and $0.90 \%$, respectively). The yields of some by-products (e.g., liver, heart, stomach, kidney and spleen) in the present study were similar the yields reported for those of pork in literature (Ockerman and Basu, 2004). Florek et al. (2012) recently reported the higher average weights of liver $(3.09 \mathrm{~kg})$, kidney $(0.587 \mathrm{~kg})$ and heart $(1.0 \mathrm{~kg})$ for suckler beef. Similarly, Ockerman and Basu (2004) reported that beef heart accounts for 0.3 to $0.5 \%$ of the live weight, liver from $1 \%$ to $4.5 \%$, lung from $0.4 \%$ to $0.8 \%$ and pancreas $0.06 \%$. The differences in yields could be attributed due to the differences in type of offal and animal species.

\section{Proximate composition of pork by-products}

The mean values of proximate composition of pork byproducts are summarized in Table 2. Small intestine and uterus had the highest moisture content $(82.48 \%$ and $80.69 \%$, respectively), while lung and heart had significantly lower moisture contents $(78.71 \%$ and $75.87 \%$, respectively), whereas liver, large intestine and pancreas contain the least moisture contents $(71.59 \%, 69.73 \%$ and $72.20 \%$, respectively) $(p<0.05)$. The moisture content of pork liver in the present study was almost equal to the values reported for liver of similar species (Kim et al., 2008) and buffalo liver (Devatkal et al., 2004). However, the moisture content of small intestine, uterus, lung and heart were higher whereas the moisture content of the

Table 1. Yield of pork by-products based on live weight

\begin{tabular}{ccc}
\hline \hline Item & Yield $(\mathrm{kg})$ & Ratio $(\%)$ \\
\hline Live weight & $134.81 \pm 17.07$ & \\
Heart & $0.44 \pm 0.07^{*}$ & $0.33 \pm 0.04$ \\
Liver & $1.82 \pm 0.34$ & $1.35 \pm 0.18$ \\
Lung & $0.71 \pm 0.10$ & $0.53 \pm 0.09$ \\
Stomach & $0.75 \pm 0.11$ & $0.56 \pm 0.08$ \\
Small intestine & $1.17 \pm 0.23$ & $0.86 \pm 0.10$ \\
Large intestine & $1.23 \pm 0.33$ & $0.90 \pm 0.15$ \\
Spleen & $0.22 \pm 0.04$ & $0.16 \pm 0.02$ \\
Uterus & $0.58 \pm 0.28$ & $0.42 \pm 0.19$ \\
Pancreas & $0.24 \pm 0.08$ & $0.18 \pm 0.06$ \\
\hline
\end{tabular}

*Mean \pm standard error. 
Table 2. Proximate composition and caloric content of pork by-products

\begin{tabular}{|c|c|c|c|c|c|c|c|c|c|}
\hline Item & Heart & Liver & Lung & Stomach & $\begin{array}{c}\text { Small } \\
\text { intestine }\end{array}$ & $\begin{array}{c}\text { Large } \\
\text { intestine }\end{array}$ & Spleen & Uterus & Pancreas \\
\hline Moisture (\%) & $75.87 \pm 2.09^{* d}$ & $71.59 \pm 3.42^{\mathrm{e}}$ & $78.71 \pm 0.78^{\mathrm{bc}}$ & $77.63 \pm 1.51^{\mathrm{cd}}$ & $82.48 \pm 2.05^{\mathrm{a}}$ & $69.73 \pm 4.70^{\mathrm{e}}$ & $78.58 \pm 0.89^{\mathrm{bc}}$ & $80.69 \pm 2.19^{\mathrm{ab}}$ & $72.20 \pm 3.45^{\mathrm{e}}$ \\
\hline Fat $(\%)$ & $4.55 \pm 1.46^{\mathrm{c}}$ & $2.94 \pm 0.50^{\mathrm{de}}$ & $1.79 \pm 0.43^{\mathrm{ef}}$ & $4.05 \pm 1.31^{\mathrm{cd}}$ & $1.16 \pm 0.89^{f}$ & $19.54 \pm 3.24^{\mathrm{a}}$ & $0.97 \pm 0.21^{\mathrm{f}}$ & $0.28 \pm 0.17^{\mathrm{f}}$ & $7.18 \pm 1.34^{\mathrm{b}}$ \\
\hline Ash (\%) & $0.81 \pm 0.13^{\mathrm{c}}$ & $1.34 \pm 0.11^{\mathrm{a}}$ & $0.76 \pm 0.11^{\mathrm{c}}$ & $0.31 \pm 0.15^{\mathrm{e}}$ & $0.30 \pm 0.07^{\mathrm{e}}$ & $0.15 \pm 0.08^{f}$ & $1.12 \pm 0.07^{\mathrm{b}}$ & $0.50 \pm 0.13^{\mathrm{d}}$ & $1.26 \pm 0.16^{\mathrm{a}}$ \\
\hline Protein $(\%)$ & $17.62 \pm 0.43^{\mathrm{b}}$ & $22.05 \pm 1.38^{\mathrm{a}}$ & $16.6 \pm 0.73^{b}$ & $17.07 \pm 0.18^{b}$ & $11.99 \pm 0.65^{\mathrm{d}}$ & $8.45 \pm 1.38^{\mathrm{e}}$ & $17.79 \pm 0.33^{b}$ & $15.05 \pm 1.65^{\mathrm{c}}$ & $20.98 \pm 0.97^{\mathrm{a}}$ \\
\hline $\begin{array}{l}\text { Calorie } \\
\text { (cal/g) }\end{array}$ & $\begin{array}{c}1,708.30 \pm \\
120.63^{\mathrm{c}}\end{array}$ & $\begin{array}{c}1,850.60 \pm \\
65.24^{\mathrm{bc}}\end{array}$ & $\begin{array}{c}1,357.20 \pm \\
98.53^{\mathrm{d}}\end{array}$ & $\begin{array}{c}1,416.60 \pm \\
65.36^{\mathrm{d}}\end{array}$ & $\begin{array}{c}1,136.10 \pm \\
181.07^{\mathrm{e}}\end{array}$ & $\begin{array}{c}2,601.00 \pm \\
272.93^{\mathrm{a}}\end{array}$ & $\begin{array}{c}1,282.50 \pm \\
60.47^{\mathrm{de}}\end{array}$ & $\begin{array}{c}1,136.75 \pm \\
112.92^{\mathrm{e}}\end{array}$ & $\begin{array}{c}1,916.13 \pm \\
199.28^{\mathrm{b}}\end{array}$ \\
\hline
\end{tabular}

Means in the same row with different superscripts (a-g) are significantly different $(p<0.05)$.

*Mean \pm standard error.

liver, large intestine and pancreas were lower than the moisture content $(73.2 \%)$ of muscle tissues of similar species reported in literature (Ngapo et al., 2012). Among the pork by-products examined, the large intestine had the highest fat content $(19.54 \%)$, followed by pancreas (7.18\%), stomach (4.05\%), liver (2.94\%), small intestine $(1.16 \%)$, spleen $(0.97 \%)$ and uterus $(0.28 \%)$. The results of fat contents are in good agreement with the results of Honikel (2011). Furthermore, the levels of fat contents in heart, liver and pancreas in the present study were similar the fat levels reported for those of similar species by Ockerman and Basu (2004). On the other hand, the fat contents in large intestine, pancreas, liver, heart and stomach were higher than the values (1.84-2.58\%) reported for muscle tissue of pork (Chanon et al., 2004; Ngapo et al., 2012) but similar to the fat content $(5.86-25.97 \%)$ of muscle tissues of different beef breeds (Ba et al., 2014; Moon et al., 2006; Okumura et al., 2012). Daily fat intake is important for human health because the fat not only contributes to energy intake but also helps vitamin absorbance; however a high daily fat intake has been associated with obesity and cardiovascular disease (Bray et al., 2004). In the present study, the fat levels of pork by-products are generally similar or even lower than the fat contents of muscle tissues.

Liver had the highest ash content (1.34\%); spleen had significantly lower ash content $(1.12 \%)$, whereas large intestine had the least ash content $(p<0.05)$. Heart and lung had similar ash contents $(0.81 \%$ and $0.76 \%$, respectively), stomach and small intestine had similar ash values $(0.31 \%$ and $0.30 \%$, respectively). The ash content of pork liver was similar as the ash content reported for the buffalo liver (Devatkal et al., 2004) and pork products (Marustic et al., 2011). The ash content is an important factor reflecting the nutritional value, quality and physicochemical properties of foods (Keran et al., 2009).

Liver and pancreas had the highest protein contents (20.98\% and $22.05 \%$, respectively) that were similar the protein content (20\%) of all common meat species reported in literature (Honikel and Wellhauser, 1993) while heart, lung, stomach and spleen had lower protein content $(17 \%)$, whereas large intestine contain the least protein $(8.45 \%)(p<0.05)$. Furthermore, the protein content of pork liver in the present study was similar to the values reported for liver of similar species in literatures (Kim et al., 2008; Ockerman and Basu, 2004). The nutritional energy in the pork by-products showed that the large intestine had the highest energy; this could be attributed due to its high fat content. While the liver and pancreas had significantly lower energy content whereas small intestine, spleen and uterus had the lowest energy content $(p<0.05)$. The energy content of these by-products was generally higher than the values reported for beef byproducts (Honikel 2011) and this could be attributed by the high fat content in the pork by-products compared to beef by-products as discussed above. The recommended daily allowance for an adult is $60 \mathrm{~g}$ protein, $90 \mathrm{~g}$ dietary fat and 2,500 kcal. Therefore for example, a consuming $100 \mathrm{~g}$ of pork liver would supply $36 \%$ of protein, $3.2 \%$ fat and $7.4 \%$ total energy.

\section{Vitamin content in pork by-products}

The mean values of vitamins in the pork by-products are presented in Table 3. Our results showed that the vitamin contents varied among the examined pork by-products. Particularly the liver had the highest concentrations of vitamin A $(57,406.68 \mu \mathrm{g} R \mathrm{RE} / 100 \mathrm{~g})$, vitamin B2 (0.92 $\mathrm{mg} / 100 \mathrm{~g})$ and vitamin B6 $(0.12 \mathrm{mg} / 100 \mathrm{~g})$; heart had the highest amount of vitamin B1; and pancreas had the highest niacin content. While the similar amount of vitamin A was observed for heart, lung, stomach, small intestine, large intestine, spleen and pancreas. The vitamin A content of pork liver was several times greater than the values $(16,898 \mu \mathrm{g} R E / 100 \mathrm{~g}$ and $24.612 \mu \mathrm{g} R / 100 \mathrm{~g}$, respectively) reported for beef liver and lamb liver (Kim, 2011) but much higher than the value $(5 \mu \mathrm{g} R / 100 \mathrm{~g})$ reported 
Table 3. Vitamin contents $(\mathrm{mg} / 100 \mathrm{~g})$ of pork by-products

\begin{tabular}{|c|c|c|c|c|c|c|c|c|c|}
\hline Item & Heart & Liver & Lung & Stomach & $\begin{array}{c}\text { Small } \\
\text { intestine }\end{array}$ & $\begin{array}{l}\text { Large } \\
\text { intestine }\end{array}$ & Spleen & Uterus & Pancreas \\
\hline $\begin{array}{c}\text { Vitamin A } \\
\left.\mu \mathrm{g} \mathrm{RE} / 100 \mathrm{~g}^{-1}\right)\end{array}$ & & $\begin{array}{c}57.406 .68 \pm \\
125^{\mathrm{a}}\end{array}$ & & & $45.01 \pm 23$. & 51.53 & & & \\
\hline Vitamin B1 & & $0.13 \pm 0.02^{b}$ & & & $0.07 \pm 0.00^{\mathrm{d}}$ & $0.07 \pm 0.01^{\mathrm{d}}$ & $0.10 \pm 0.02^{\mathrm{c}}$ & $0.04 \pm 0.01^{\mathrm{e}}$ & $0.11 \pm 0.01^{\mathrm{c}}$ \\
\hline Vitam & & $0.92 \pm 0.09^{\mathrm{a}}$ & & & $0.10 \pm 0.00^{\mathrm{e}}$ & $0.05 \pm 0.01^{\mathrm{f}}$ & $0.09 \pm$ & & 0.22 \\
\hline & & & & & $4.20 \pm 0.33^{c}$ & $1.13 \pm 0.12^{\mathrm{c}}$ & & & $\begin{array}{c}214.01 \pm \\
14.09^{\mathrm{a}}\end{array}$ \\
\hline & & & & & $1.45 \pm 0.34^{\mathrm{bc}}$ & $1.57 \pm 0.45^{\mathrm{bc}}$ & & & \\
\hline Vitamin B6 & ND & $0.12 \pm 0.01^{\mathrm{a}}$ & $0.02 \pm 0.00^{b}$ & $0.02 \pm 0.00^{\mathrm{bc}}$ & $0.01 \pm 0.00^{\mathrm{c}}$ & $0.01 \pm 0.00^{\mathrm{c}}$ & $0.01 \pm 0.00^{\mathrm{c}}$ & $0.01 \pm 0.00^{\mathrm{c}}$ & ND \\
\hline
\end{tabular}

Means in the same row with different superscripts (a-f) are significantly different $(p<0.05)$.

*Mean \pm standard error.

ND, not detectable.

for beef muscle (Honikel, 2011). However, the vitamin B1 and B2 contents in these pork by-products were lower than the values reported for beef and lamb by-products (Kim, 2011). These contrasting results of vitamin contents could be attributed due to the differences in animal species. Vitamins are essential compounds that maintain the normal function and metabolic reactions in the body. In the present study, it was observed that the amounts of most of vitamins in these pork by-products were considerably higher than those in muscle tissues. This is in agreement with the previous observations of Kim (2011) which indicated that internal organs have more vitamin contents than muscle tissues. Moreover, the outcome of our analysis showed that the concentrations of vitamins B in all pork by-products were comparable to grain, cerealgrain food and soy-products, which are well recognized as the richest sources of vitamins B (Lebiedzinska and Szefer, 2006).

\section{Amino acid content of pork by-products}

Table 4 shows the relative percentage of essential and non-essential amino acids in different pork by-products. Our results depict that the levels of both essential and non-essential amino acids show a large variation among the examined pork by-products. Particularly, the liver had the highest levels of most of the essential amino acids (EAA) such as threonine, valine, isoleucine, leucine, tyrosine, phynylalanine, lysine and histidine. Whereas, uterus, small and large intestines had the lowest levels of most of EAA. Pancreas had the highest level of methionine, while the levels of valine and leucine were similar to that of liver. Also, pancreas had higher threonine, valine and histidine levels than heart, lung, uterus, small and large intestines. Similarly, the liver had the highest total amino acids $(21.07 \%)$, followed by pancreas $(18.65 \%)$, uterus (14.76\%), small and large intestines $(10.83 \%$ and $7.66 \%$, respectively). These results are consistent with the protein levels (Table 2). Our results are in good agreement with the findings of Anderson (1988). He also reported that pork by-products contain varying levels of amino acids and the levels of the essential amino acids were nearly similar to that of muscle tissues.

The EAAs are very important compositions because they cannot be produced by the body and must be supplied in the diet. Without these essential amino acids, the body is unable to function normally; also the presence of amino acids also enables vitamins and minerals to perform all their physiological functions (Wu, 2010). Edible meat by-products have been found to be a source of important nutrients like essential amino acids and among them proteins of the internal organs have higher biological value than other by-products (e.g., blood, tongue, ear etc) with a balanced essential amino acid content similar to that of muscle proteins (Aristoy and Toldra, 2011). Furthermore, earlier workers (Aristoy and Toldra, 2011) also reported that levels of the essential amino acids in meat by-products are not remarkably diminished after cooking or heating treatment due to the low-reducing sugar content of these by-products does not cause secondary degradation reactions such as the Maillard reaction. From our observations it can be concluded that the pork by-products especially liver, pancreas and spleen are good sources of EAAs. Additionally, we also assume that the differences in levels and types of amino acid contents may be attributed due to the differences in protein types (e.g., collagen, myofibril protein etc.) among the by-products.

\section{Mineral content in pork by-products}

The concentration of minerals in the pork by-products is summarized in Table 5. Calcium $(\mathrm{Ca})$, phosphorous $(\mathrm{P})$, potassium $(\mathrm{K})$, sodium $(\mathrm{Na})$ and magnesium $(\mathrm{Mg})$ are marcroelements. Our results depict that the concentra- 
Table 4. Amino acid composition (\%) of pork by-products

\begin{tabular}{|c|c|c|c|c|c|c|c|c|c|}
\hline Item & Heart & Liver & Lung & Stomach & $\begin{array}{c}\text { Small } \\
\text { intestine }\end{array}$ & $\begin{array}{c}\text { Large } \\
\text { intestine }\end{array}$ & Spleen & Uterus & Pancreas \\
\hline \multicolumn{10}{|c|}{ Essential amino acid } \\
\hline Met & $0.21 \pm 0.01^{* \mathrm{c}}$ & $0.36 \pm 0.01^{\mathrm{b}}$ & $0.20 \pm 0.01^{\mathrm{d}}$ & $0.21 \pm 0.01^{\mathrm{c}}$ & $0.15 \pm 0.01^{\mathrm{d}}$ & $0.10 \pm 0.01^{\mathrm{e}}$ & $0.23 \pm 0.02^{\mathrm{c}}$ & $0.23 \pm 0.04^{\mathrm{d}}$ & $0.42 \pm 0.02^{\mathrm{a}}$ \\
\hline Thr & & $0.45 \pm 0.02^{\mathrm{a}}$ & & $0.33 \pm 0.02^{\mathrm{c}}$ & $0.21 \pm 0.02^{\mathrm{e}}$ & $0.14 \pm 0.02^{\mathrm{f}}$ & $0.32 \pm 0.02^{\mathrm{c}}$ & $0.57 \pm 0.04^{\mathrm{d}}$ & $0.32 \pm 0.03^{\mathrm{b}}$ \\
\hline Val & $1.52 \pm 0.09^{\mathrm{c}}$ & $2.01 \pm 0.16^{\mathrm{a}}$ & & $1.42 \pm 0.06^{\mathrm{c}}$ & $0.88 \pm 0.08^{\mathrm{e}}$ & $0.64 \pm 0.07^{\mathrm{f}}$ & $1.54 \pm 0.05^{\mathrm{b}}$ & $0.57 \pm 0.04^{\mathrm{d}}$ & $2.09 \pm 0.07^{\mathrm{a}}$ \\
\hline I-le & $0.76 \pm 0.0$ & $1.02 \pm 0.08^{\mathrm{a}}$ & & & $0.46 \pm 0.04^{\mathrm{f}}$ & $0.33 \pm 0.03^{\mathrm{g}}$ & & $0.4 \pm 0.04^{\mathrm{e}}$ & $0.95 \pm 0.03^{\mathrm{b}}$ \\
\hline Leu & $0.71 \pm 0.04^{\mathrm{bc}}$ & $1.05 \pm 0.08^{\mathrm{a}}$ & $0.72 \pm 0.02^{\mathrm{d}}$ & $0.80 \pm 0.04^{\mathrm{d}}$ & $0.50 \pm 0.04^{\mathrm{f}}$ & $0.36 \pm 0.03^{\mathrm{g}}$ & $0.80 \pm 0.02^{\mathrm{c}}$ & $1.02 \pm 0.08^{\mathrm{e}}$ & $1.11 \pm 0.04^{\mathrm{a}}$ \\
\hline Phe & & $1.29 \pm 0.12^{\mathrm{a}}$ & $1.61 \pm 0.09^{\mathrm{c}}$ & $1.63 \pm 0.08^{\mathrm{d}}$ & $1.01 \pm 0.17^{\mathrm{e}}$ & $0.77 \pm 0.06^{\mathrm{f}}$ & $1.07 \pm 0.04^{\mathrm{c}}$ & & \\
\hline Lys & $1.05 \pm 0.04^{\mathrm{b}}$ & $1.33 \pm 0.11^{\mathrm{a}}$ & $1.17 \pm 0.05^{\mathrm{c}}$ & $1.06 \pm 0.05^{\mathrm{c}}$ & $0.67 \pm 0.08^{\mathrm{d}}$ & $0.47 \pm 0.06^{\mathrm{e}}$ & $1.05 \pm 0$. & $1.18 \pm 0.08^{\mathrm{c}}$ & $1.11 \pm 0.04^{\mathrm{b}}$ \\
\hline His & & $1.10 \pm 0.08^{\mathrm{a}}$ & & $0.66 \pm 0.03^{\mathrm{d}}$ & $0.43 \pm 0.04^{\mathrm{e}}$ & $0.30 \pm 0.04^{\mathrm{f}}$ & & & $1.06 \pm 0.04^{\mathrm{b}}$ \\
\hline \multicolumn{10}{|c|}{ Non-Essential amino acid } \\
\hline Ser & $0.61 \pm 0.04^{b}$ & $0.87 \pm 0.06^{\mathrm{a}}$ & & $0.51 \pm 0.04^{\mathrm{c}}$ & $0.33 \pm 0.03^{\mathrm{d}}$ & $0.24 \pm 0.03^{\mathrm{e}}$ & $0.53 \pm 0.02^{\mathrm{c}}$ & $0.68 \pm 0.05^{\mathrm{d}}$ & $0.81 \pm 0.02^{\mathrm{c}}$ \\
\hline Tyr & $2.53 \pm 0.22^{\mathrm{c}}$ & $2.93 \pm 0.21^{\mathrm{a}}$ & $1.97 \pm 0.07^{\mathrm{d}}$ & $2.32 \pm 0.06^{\mathrm{c}}$ & $1.47 \pm 0.16^{\mathrm{f}}$ & $1.06 \pm 0.12^{\mathrm{g}}$ & $2.39 \pm 0.07^{\mathrm{b}}$ & $0.43 \pm 0.02^{\mathrm{e}}$ & $2.34 \pm 0.11^{\mathrm{b}}$ \\
\hline Glu & $1.49 \pm 0.10^{\mathrm{c}}$ & $2.11 \pm 0.16^{\mathrm{a}}$ & $1.30 \pm 0.03^{\mathrm{d}}$ & $1.23 \pm 0.04^{\mathrm{c}}$ & $0.81 \pm 0.08^{\mathrm{e}}$ & $0.57 \pm 0.07^{\mathrm{f}}$ & $1.41 \pm 0.05^{\mathrm{c}}$ & $2.1 \pm 0.23^{\mathrm{d}}$ & $1.54 \pm 0.06^{\mathrm{b}}$ \\
\hline Gly & $0.55 \pm 0.04^{\mathrm{c}}$ & $0.77 \pm 0.07^{\mathrm{a}}$ & $0.48 \pm 0.03^{b}$ & $0.53 \pm 0.02^{\mathrm{c}}$ & $0.35 \pm 0.03^{\mathrm{e}}$ & $0.25 \pm 0.02^{\mathrm{f}}$ & $0.57 \pm 0.01^{\mathrm{b}}$ & $1.85 \pm 0.35^{\mathrm{d}}$ & $0.83 \pm 0.02^{\mathrm{a}}$ \\
\hline Ala & $0.74 \pm 0.04^{c}$ & $1.11 \pm 0.11^{\mathrm{a}}$ & $0.73 \pm 0.02^{\mathrm{e}}$ & $0.65 \pm 0.03^{\mathrm{d}}$ & $0.52 \pm 0.05^{\mathrm{f}}$ & $0.41 \pm 0.05^{\mathrm{g}}$ & $0.80 \pm 0.02^{\mathrm{d}}$ & $1.07 \pm 0.13^{\mathrm{e}}$ & $0.97 \pm 0.04^{b}$ \\
\hline Asp & $1.43 \pm 0.07^{\mathrm{bc}}$ & $1.69 \pm 0.12^{\mathrm{a}}$ & $1.09 \pm 0.04^{\mathrm{d}}$ & $1.15 \pm 0.06^{\mathrm{d}}$ & $0.89 \pm 0.04^{\mathrm{f}}$ & $0.75 \pm 0.08^{\mathrm{g}}$ & $1.39 \pm 0.07^{\mathrm{c}}$ & $1.23 \pm 0.12^{\mathrm{e}}$ & $1.36 \pm 0.06^{\mathrm{b}}$ \\
\hline Cys & $0.47 \pm 0.02^{\mathrm{c}}$ & $0.64 \pm 0.05^{\mathrm{b}}$ & $0.47 \pm 0.03^{\mathrm{d}}$ & $0.37 \pm 0.02^{\mathrm{c}}$ & $0.32 \pm 0.04^{\mathrm{f}}$ & $0.24 \pm 0.03^{\mathrm{g}}$ & $0.53 \pm 0.02^{\mathrm{c}}$ & $0.2 \pm 0.01^{\mathrm{e}}$ & $0.53 \pm 0.02^{\mathrm{a}}$ \\
\hline Arg & $1.00 \pm 0.05^{\mathrm{c}}$ & $1.22 \pm 0.09^{\mathrm{a}}$ & $0.91 \pm 0.04^{\mathrm{c}}$ & $1.03 \pm 0.02^{\mathrm{d}}$ & $0.78 \pm 0.06^{\mathrm{e}}$ & $0.62 \pm 0.07^{\mathrm{f}}$ & $1.00 \pm 0.03^{\mathrm{c}}$ & $0.99 \pm 0.11^{\mathrm{d}}$ & $1.07 \pm 0.03^{\mathrm{b}}$ \\
\hline Pro & $0.78 \pm 0.04^{b}$ & $1.11 \pm 0.09^{\mathrm{a}}$ & $1.08 \pm 0.05^{\mathrm{c}}$ & $1.12 \pm 0.05^{\mathrm{c}}$ & $0.69 \pm 0.10^{\mathrm{d}}$ & $0.46 \pm 0.07^{\mathrm{e}}$ & $0.82 \pm 0.04^{b}$ & $1.22 \pm 0.18^{\mathrm{c}}$ & $0.94 \pm 0.03^{\mathrm{b}}$ \\
\hline Total & $15.88 \pm 0.91^{\mathrm{c}}$ & $21.07 \pm 1.58^{\mathrm{a}}$ & $15.07 \pm 0.43^{\mathrm{c}}$ & $15.73 \pm 0.51^{\mathrm{c}}$ & $10.83 \pm 0.50^{\mathrm{e}}$ & $7.66 \pm 0.84^{f}$ & $15.99 \pm 0.44^{\mathrm{c}}$ & $14.76 \pm 1.50^{\mathrm{d}}$ & $18.65 \pm 0.66^{b}$ \\
\hline
\end{tabular}

Means in the same row with different superscripts (a-f) are significantly different $(p<0.05)$.

*Mean \pm standard error.

Table 5. Mineral content $(\mathrm{mg} / \mathrm{kg})$ of pork by-products

\begin{tabular}{|c|c|c|c|c|c|c|c|c|c|}
\hline Item & Heart & Liver & Lung & Stomach & $\begin{array}{c}\text { Small } \\
\text { intestine }\end{array}$ & $\begin{array}{c}\text { Large } \\
\text { intestine }\end{array}$ & Spleen & Uterus & Pancreas \\
\hline $\mathrm{Ca}$ & $64.13 \pm 9.52^{* d}$ & $70.40 \pm 5.42^{\mathrm{d}}$ & $132.48 \pm 14.43^{\mathrm{c}}$ & $125.13 \pm 11.86^{\mathrm{c}}$ & $175.24 \pm 35.44^{b}$ & $198.57 \pm 46.04^{b}$ & $73.83 \pm 7.10^{\mathrm{d}}$ & $122.17 \pm 14.05^{\circ}$ & $217.01 \pm 19.63^{\mathrm{a}}$ \\
\hline $\mathrm{P}$ & $\begin{array}{c}1870.75 \pm \\
64.23^{\mathrm{c}}\end{array}$ & $\begin{array}{c}2477.24 \pm \\
117.37^{\mathrm{b}}\end{array}$ & $\begin{array}{c}1891.10 \pm \\
103.53^{\mathrm{c}}\end{array}$ & $\begin{array}{c}1394.79 \pm \\
84.36^{\mathrm{d}}\end{array}$ & $\begin{array}{c}1194.39 \pm \\
142.47^{\mathrm{e}}\end{array}$ & $\begin{array}{c}610.24 \pm \\
63.90^{\mathrm{f}}\end{array}$ & $\begin{array}{c}2570.4 \pm \\
92.54^{\mathrm{b}}\end{array}$ & $\begin{array}{c}1178.94 \pm \\
145.10^{\mathrm{e}}\end{array}$ & $\begin{array}{c}3147.66 \pm \\
198.64^{\mathrm{a}}\end{array}$ \\
\hline K & $\begin{array}{c}2353.79 \pm \\
202.73^{\mathrm{c}}\end{array}$ & $\begin{array}{c}3028.29 \pm \\
185.84^{\mathrm{b}}\end{array}$ & $\begin{array}{c}2027.41 \pm \\
245.98^{\mathrm{d}}\end{array}$ & $\begin{array}{c}1782.08 \pm \\
65.11^{\mathrm{d}}\end{array}$ & $\begin{array}{c}1129.66 \pm \\
265.72^{\mathrm{e}}\end{array}$ & $\begin{array}{c}404.84 \pm \\
38.90^{\mathrm{f}}\end{array}$ & $\begin{array}{c}3399.66 \pm \\
165.67^{\mathrm{a}}\end{array}$ & $\begin{array}{l}1312.3 \pm \\
234.42^{\mathrm{e}}\end{array}$ & $\begin{array}{c}3078.21 \pm \\
150.72^{\mathrm{b}}\end{array}$ \\
\hline $\mathrm{Na}$ & $\begin{array}{c}1332.31 \pm \\
186.49^{\mathrm{b}}\end{array}$ & $\begin{array}{c}951.65 \pm \\
40.13^{\mathrm{c}}\end{array}$ & $\begin{array}{l}1929.6 \pm \\
216.91^{\mathrm{a}}\end{array}$ & $\begin{array}{c}1205.43 \pm \\
43.88^{\mathrm{b}}\end{array}$ & $\begin{array}{l}537.02 \pm \\
106.94^{\mathrm{d}}\end{array}$ & $\begin{array}{c}225.29 \pm \\
29.12^{\mathrm{e}}\end{array}$ & $\begin{array}{c}879.25 \pm \\
32.78^{\mathrm{c}}\end{array}$ & $\begin{array}{c}1949.66 \pm \\
91.84^{\mathrm{a}}\end{array}$ & $\begin{array}{c}846.62 \pm \\
87.79^{c}\end{array}$ \\
\hline $\mathrm{Mg}$ & $\begin{array}{c}198.73 \pm \\
18.40^{\mathrm{bc}}\end{array}$ & $\begin{array}{c}210.14 \pm \\
8.99^{\mathrm{b}}\end{array}$ & $\begin{array}{c}137.14 \pm \\
12.96^{\mathrm{d}}\end{array}$ & $\begin{array}{c}177.34 \pm \\
21.43^{\mathrm{c}}\end{array}$ & $\begin{array}{c}124.55 \pm \\
18.20^{\text {de }}\end{array}$ & $\begin{array}{c}103.01 \pm \\
18.46^{\mathrm{e}}\end{array}$ & $\begin{array}{c}179.68 \pm \\
6.89^{\mathrm{c}}\end{array}$ & $\begin{array}{c}103.04 \pm \\
15.34^{\mathrm{e}}\end{array}$ & $\begin{array}{c}233.06 \pm \\
15.15^{\mathrm{a}}\end{array}$ \\
\hline $\mathrm{Fe}$ & $34.58 \pm 6.33^{\mathrm{d}}$ & $148.40 \pm 31.90^{\mathrm{b}}$ & $63.01 \pm 16.65^{\mathrm{c}}$ & $11.05 \pm 1.30^{\mathrm{e}}$ & $22.56 \pm 4.17^{\mathrm{de}}$ & $11.69 \pm 1.99^{\mathrm{e}}$ & $178.54 \pm 27.65^{\mathrm{a}}$ & $1.26 \pm 0.29^{\mathrm{e}}$ & $37.97 \pm 3.21^{\mathrm{d}}$ \\
\hline Mn & $0.65 \pm 0.21^{\mathrm{d}}$ & $2.98 \pm 0.20^{\mathrm{a}}$ & $0.36 \pm 0.05^{\mathrm{e}}$ & $0.76 \pm 0.05^{\mathrm{d}}$ & $1.22 \pm 0.10^{\mathrm{c}}$ & $0.63 \pm 0.25^{\mathrm{d}}$ & $0.53 \pm 0.17^{\mathrm{de}}$ & $0.62 \pm 0.20^{\mathrm{d}}$ & $1.98 \pm 0.13^{\mathrm{b}}$ \\
\hline $\mathrm{Zn}$ & $1.83 \pm 0.22^{\mathrm{d}}$ & $7.04 \pm 0.89^{\mathrm{a}}$ & $1.53 \pm 0.10^{\mathrm{def}}$ & $1.77 \pm 0.17^{\mathrm{de}}$ & $1.92 \pm 0.33^{\mathrm{d}}$ & $1.24 \pm 0.18^{\mathrm{f}}$ & $2.63 \pm 0.19^{c}$ & $1.30 \pm 0.13^{\mathrm{ef}}$ & $3.83 \pm 0.29^{\mathrm{b}}$ \\
\hline $\mathrm{Cu}$ & $3.06 \pm 0.56^{\mathrm{b}}$ & $5.50 \pm 1.26^{\mathrm{a}}$ & $1.17 \pm 0.30^{\mathrm{c}}$ & $1.43 \pm 0.13^{\mathrm{c}}$ & $1.41 \pm 0.26^{\mathrm{c}}$ & $0.88 \pm 0.13^{\mathrm{c}}$ & $1.18 \pm 0.30^{\mathrm{c}}$ & $1.53 \pm 0.23^{\mathrm{c}}$ & $1.55 \pm 0.24^{\mathrm{c}}$ \\
\hline $\mathrm{Cr}$ & $0.26 \pm 0.10^{\mathrm{ab}}$ & $0.32 \pm 0.14^{\mathrm{a}}$ & $0.14 \pm 0.08^{\mathrm{bc}}$ & $0.22 \pm 0.07^{\mathrm{abc}}$ & $0.29 \pm 0.20^{\mathrm{ab}}$ & $0.07 \pm 0.05^{\mathrm{c}}$ & $0.40 \pm 0.09^{\mathrm{a}}$ & $0.09 \pm 0.02^{\mathrm{c}}$ & $0.33 \pm 0.22^{\mathrm{a}}$ \\
\hline
\end{tabular}

Means in the same row with different superscripts (a-f) are significantly different $(p<0.05)$.

*Mean \pm standard error.

tions of these minerals vary among the by-products. The concentration of $\mathrm{Ca}(217.01 \mathrm{mg} / \mathrm{kg}), \mathrm{P}(3147.66 \mathrm{mg} / \mathrm{kg})$ and $\mathrm{Mg}(233.06 \mathrm{mg} / \mathrm{kg})$ in pancreas were significantly higher than that in other remaining by-products $(p<0.05)$. Spleen had significantly high K content, followed by liver, heart, small and large intestines $(p<0.05)$. Whereas, lung and uterus had the highest $\mathrm{Na}$ content, followed by small and large intestine, while heart and stomach had similar sodium content. The concentrations of these marcroele- ments in pork liver were higher than the reported values of buffalo liver (Devatkal et al., 2004). Similarly, the concentrations of $\mathrm{P}, \mathrm{K}, \mathrm{Na}$ and $\mathrm{Mg}$ in pancreas were higher than the values reported for beef pancreas (Ockerman and Basu, 2004) and dry-cured hams (Jiménez-Colmenero et al., 2010).

Iron $(\mathrm{Fe})$, manganese $(\mathrm{Mn})$, zinc $(\mathrm{Zn})$, copper $(\mathrm{Cu})$ and chromium $(\mathrm{Cr})$ are trace elements which are vital for maintaining human health; an insufficient intake of these 
trace minerals can cause symptoms of nutritional deficiency (Tapiero and Tew, 2003). Amongst, iron is one of the vital minerals needed for the optimum function of blood; iron deficiency causes anemia, especially in pregnant women and children (Benoist, 2001). The outcome of our analysis showed that the spleen had the highest Fe content $(178.54 \mathrm{mg} / \mathrm{kg})$, followed by liver, lung and pancreas; stomach, uterus, small and large intestines contain the least Fe content. It was observed that the Fe contents of all pork by-products were much higher than the Fe contents $(8.5 \mathrm{mg} / \mathrm{kg}$ and $18 \mathrm{mg} / \mathrm{kg}$, respectively) of pork meat and dry-cured hams (Garcia-Llatas et al. 2011; JiménezColmenero et al., 2010). Pereira and Vicente (2013) reported the much lower Fe contents in breast chicken ( 5 $\mathrm{mg} / \mathrm{kg})$, beef loin $(15 \mathrm{mg} / \mathrm{kg})$ and mutton chops $(17 \mathrm{mg} /$ $\mathrm{kg})$. Additionally, the Fe content $(148.4 \mathrm{mg} / \mathrm{kg})$ in liver in the present study was higher than the value $(49 \mathrm{mg} / \mathrm{kg}$ ) reported for beef liver (Garcia-Llatas et al., 2011). On the other hand, the Fe content in spleen, liver, heart and lung is heme iron; its absorption is several times greater than the non-heme iron present in other foods (Devatkal et al., 2004). Furthermore, we also observed that the liver had the highest amounts of $\mathrm{Mn}, \mathrm{Zn}$ and $\mathrm{Cu}$ while the pancreas had higher $\mathrm{Mn}$ and $\mathrm{Zn}$ contents whereas lung, stomach, small and large intestines contain the least concentrations of these minerals. However, these values were slightly lower than the values reported for beef by-products (Garcia-Llatas et al., 2011) and dry-cured hams (Jiménez-Colmenero et al., 2010). Our results are in agreement with the observation of Garcia-Llatas et al. (2011) that organ tissues had significantly higher concentrations of minerals than muscle tissues. Therefore, from our results it is summarized that almost pork by-products are rich sources of marcroelements while spleen, liver and pancreas are rich sources of trace elements such as Fe and Zn. Recommended daily intake for iron content is $10 \mathrm{mg}$ per day for an adult (Honikel, 2011); therefore serving of $100 \mathrm{~g}$ pork liver or $100 \mathrm{~g}$ spleen ensures more than $100 \%$ of iron requirement.

\section{Fatty acid composition of pork by-products}

The fatty acid composition of different pork by-products is shown in Table 6. There was a significant difference in the fatty acid composition between the pork by-

Table 6. Fatty acid composition (mean values $\%$ of total $\pm \mathrm{SE}$ ) of pork by-products

\begin{tabular}{|c|c|c|c|c|c|c|c|c|c|}
\hline $\begin{array}{l}\text { Fatty } \\
\text { acid }\end{array}$ & Heart & Liver & Lung & Stomach & $\begin{array}{c}\text { Small } \\
\text { intestine }\end{array}$ & $\begin{array}{c}\text { Large } \\
\text { intestine }\end{array}$ & Spleen & Uterus & \\
\hline C14:0 & $1.08 \pm 0.21 * \mathrm{de}$ & $0.57 \pm 0.21^{f}$ & $1.82 \pm 0.21^{\mathrm{a}}$ & $1.44 \pm 0.58^{\mathrm{bc}}$ & $1.29 \pm 0.28^{\mathrm{bcd}}$ & $1.22 \pm 0.46^{\mathrm{cd}}$ & $0.88 \pm 0.31^{\text {eff }}$ & $1.61 \pm 0.29^{\mathrm{ab}}$ & $1.12 \pm 0.00$ \\
\hline C16:0 & & & & & $26.64 \pm 2.57^{\mathrm{b}}$ & $27.8 \pm 1.12^{\mathrm{b}}$ & & & \\
\hline $\mathrm{C} 16: \ln 7$ & $0.86 \pm 0.21^{\mathrm{b}}$ & $0.50 \pm 0.18^{c}$ & $0.91 \pm 0.18^{\mathrm{b}}$ & $1.47 \pm 0.23^{\mathrm{a}}$ & $0.90 \pm 0.27^{\mathrm{b}}$ & $0.83 \pm 0.17^{\mathrm{b}}$ & $0.53 \pm 0.3^{\mathrm{c}}$ & $1.37 \pm 0.31^{\mathrm{a}}$ & \\
\hline C18:0 & $15.91 \pm 3.22^{\mathrm{cd}}$ & $26.72 \pm 1.65^{\mathrm{a}}$ & $14.02 \pm 1.79^{\mathrm{d}}$ & & $16.62 \pm 3.63^{c}$ & $21.46 \pm 1.87^{\mathrm{b}}$ & & & \\
\hline C18:1n9 & $0.04 \pm 0.02^{\mathrm{ab}}$ & $0.03 \pm 0.01^{\mathrm{ab}}$ & $0.03 \pm 0.01^{\mathrm{b}}$ & $0.04 \pm 0.01^{\mathrm{a}}$ & $0.04 \pm 0.01^{\mathrm{ab}}$ & $0.03 \pm 0.01^{\mathrm{ab}}$ & $0.03 \pm 0.01^{\mathrm{ab}}$ & $0.04 \pm 0.01^{\mathrm{a}}$ & $28.37 \pm 1.49^{\mathrm{c}}$ \\
\hline C18:1n7 & & $5.01 \pm 2$ & $27.26 \pm 2$ & & $27.38 \pm 4.78^{b}$ & $33.15 \pm 2.26^{\mathrm{a}}$ & & & \\
\hline $\mathrm{C} 18: 2 \mathrm{n} 6$ & $20.99 \pm$ & $17.66 \pm 0$ & $14.46 \pm 2.06^{\mathrm{bc}}$ & $14.15 \pm 2$ & $18.14 \pm 3.98^{\mathrm{a}}$ & $13.61 \pm 2.76^{\mathrm{c}}$ & $12.99 \pm 3.66^{\mathrm{c}}$ & $14.34 \pm 4.98^{b c}$ & $1.49^{\mathrm{a}}$ \\
\hline $\mathrm{C} 18: 3 \mathrm{n} 6$ & $0.68 \pm 0$ & $0.43 \pm 0$ & $0.49 \pm 0.18$ & & $0.59 \pm 0.19^{\mathrm{abc}}$ & $0.62 \pm 0.14^{\mathrm{abc}}$ & & & \\
\hline $\mathrm{C} 18: 3 \mathrm{n} 3$ & $0.08=$ & $0.35 \pm 0$. & $0.09 \pm 0.0$ & $0.07 \pm 0$ & $0.08 \pm 0.02^{\mathrm{cd}}$ & $0.09 \pm 0.02^{\mathrm{cd}}$ & $0.21 \pm 0$ & $0.1 \pm$ & 0.77 \\
\hline $\mathrm{C} 20: \ln 9$ & $0.56 \pm$ & $0.19 \pm($ & $0.45 \pm 0.11^{\text {bcd }}$ & & $.32 \pm 0.1^{\mathrm{de}}$ & $0.59 \pm 0.10^{\mathrm{ab}}$ & & $0.37=$ & 0.51 \\
\hline $\mathrm{C} 20: 4 \mathrm{n} 6$ & & & & & & & & & \\
\hline $\mathrm{C} 20: 5 \mathrm{n} 3$ & & & & & $0.00 \pm 0.00$ & $0.03 \pm 0.00$ & & & \\
\hline $\mathrm{C} 22: 4 \mathrm{n} 6$ & & & $0.54 \pm 0.28^{b}$ & $0.00 \pm 0.00$ & $1.03 \pm 0.4^{\mathrm{ab}}$ & $0.19 \pm 0.00^{\mathrm{b}}$ & & $0.69 \pm 0.43^{b}$ & \\
\hline $\mathrm{C} 22: 6 \mathrm{n} 3$ & $0.29 \pm$ & $3.47 \pm 1.00^{\mathrm{a}}$ & & & ND & ND & & & \\
\hline SFA & & & & & & $50.48 \pm 2.39^{\mathrm{a}}$ & & & \\
\hline UFA & & $56.13=$ & $50.51 \pm 2$ & 56.8 & $55.45 \pm 5.94^{\text {bc }}$ & $49.52 \pm 2.39^{\mathrm{d}}$ & 51.1 & $56.42=$ & 53.3 \\
\hline MUFA & $30.06 \pm$ & $15.73 \pm 2.21^{\mathrm{e}}$ & $28.65 \pm 2.17^{\mathrm{c}}$ & $38.61 \pm 3.15^{\mathrm{a}}$ & $28.63 \pm 5.07^{\mathrm{c}}$ & $34.6 \pm 2.34^{\mathrm{abc}}$ & & $35.03 \pm 2.26^{\mathrm{a}}$ & $\pm 1.80^{\mathrm{c}}$ \\
\hline PUFA & & $40.40 \pm 2.27^{\mathrm{a}}$ & $21.86 \pm 2.50^{\mathrm{de}}$ & $18.24 \pm 3.73^{\text {ef }}$ & $26.83 \pm 6.74^{\mathrm{bcd}}$ & $14.92 \pm 3.06^{\mathrm{f}}$ & $30.16 \pm 10.8^{b}$ & $21.4 \pm 3.38^{\mathrm{ed}}$ & 23.36 \\
\hline n-3 & & $4.45 \pm 1.08^{\mathrm{a}}$ & $0.51 \pm 0.19^{b}$ & $0.45 \pm 0.09^{\mathrm{b}}$ & $0.59 \pm 0.19^{\mathrm{b}}$ & $0.63 \pm 0.14^{\mathrm{b}}$ & $0.8 \pm 0.87^{\mathrm{b}}$ & $0.60 \pm 0.31^{\mathrm{b}}$ & $0.84 \pm 0.11^{\mathrm{b}}$ \\
\hline$n-6$ & & $35.95 \pm 2.16^{\mathrm{a}}$ & $21.36 \pm 2.37^{\mathrm{de}}$ & $17.79 \pm 3.70^{\text {ef }}$ & $26.24 \pm 6.7^{\mathrm{bcd}}$ & $14.29 \pm 2.94^{\mathrm{f}}$ & $29.36 \pm 11.55^{\mathrm{b}}$ & $20.80 \pm 3.19^{\mathrm{de}}$ & $22.52 \pm 1.89^{\mathrm{cd}}$ \\
\hline$n-6 / n-3$ & $35.97 \pm 12.44^{\mathrm{bcd}}$ & $8.57 \pm 2.34^{\mathrm{d}}$ & $63.55 \pm 74.36^{\mathrm{ab}}$ & $40.86 \pm 12.42^{\mathrm{bcd}}$ & $52.68 \pm 37.71^{b c}$ & $23.06 \pm 2.79^{\mathrm{cd}}$ & $90.62 \pm 62.42^{\mathrm{a}}$ & $41.46 \pm 16.90^{\mathrm{bcd}}$ & $27.08 \pm 2.62^{\mathrm{cd}}$ \\
\hline MUFA/SFA & $0.74 \pm 0.11^{\mathrm{bc}}$ & $0.36 \pm 0.05^{\mathrm{e}}$ & $0.58 \pm 0.06^{\mathrm{d}}$ & $0.90 \pm 0.13^{\mathrm{a}}$ & $0.66 \pm 0.17^{\mathrm{cd}}$ & $0.69 \pm 0.06^{\mathrm{cd}}$ & & & $0.65 \pm 0.08^{\mathrm{cd}}$ \\
\hline PUFA/SFA & $0.77 \pm 0.36^{\mathrm{ab}}$ & $0.92 \pm 0.06^{\mathrm{a}}$ & $0.44 \pm 0.07^{\text {cde }}$ & $0.43 \pm 0.11^{\text {de }}$ & $0.62 \pm 0.19^{b c}$ & $0.30 \pm 0.07^{\mathrm{e}}$ & $0.62 \pm 0.23^{\mathrm{bc}}$ & $0.50 \pm 0.12^{\mathrm{cd}}$ & $0.50 \pm 0.07^{\mathrm{cd}}$ \\
\hline
\end{tabular}

SFA, saturated fatty acid; UFA, unsaturated fatty acid; MUFA, monounsaturated fatty acid; PUFA, polyunsaturated fatty acid

Means in the same row with different superscripts (a-f) are significantly different $(p<0.05)$.

*Mean \pm standard error

$\mathrm{ND}$, not detectable 
products. Palmitic acid (C16:0), stearic acid (C18:0), vaccenic acid (C18:1n-7) and linoleic acid (C18:2n-6) were the main fatty acids found in these pork by-products, followed by arachidonic acid (C20:4n-6). The C18:1n-9 content in these pork by-products was much lower than that in pork meat while the $\mathrm{C} 18: 2 \mathrm{n}-6, \mathrm{C} 18: 3 \mathrm{n}-3$ and $\mathrm{C} 18: 3 \mathrm{n}-6$ contents were comparable to pork meat (Mas et al., 2011). Noticeably, docosahexanoic acid (C22:6n-3), an essential fatty acid, was found only in heart, liver and spleen with the highest level (3.47\%) in the liver. Mas et al. (2011) reported a lower $\mathrm{C} 22$ : $6 \mathrm{n}-3$ content $(0.21 \%)$ in muscle tissues of similar species. Total saturated fatty acids (SFA) content was highest in large intestine, spleen and lung whereas heart, liver, stomach and uterus had the lowest total SFA content. Similarly heart, liver, stomach and uterus had the highest total unsaturated fatty acid (UFA) content while small intestine had lower total UFA content than the large intestine. Liver had the lowest $n-6 / n-3$ ratio (8.57), whereas the spleen had the highest $n-6 / n-3$ ratio (90.62), while heart, stomach and uterus had similar $n-6 /$ $n-3$ ratio. Heart and liver had the highest PUFA/SFA ratios, whereas large intestine had the lowest PUFA/SFA ratio. In general, the levels of individual fatty acids, total SFA, total UFA, n-6/n-3 and PUFA/SFA ratios in the pork byproducts were nearly similar to that in beef by-products (Mestre-Prate et al., 2011). Hoffman et al. (2013) reported higher total SFA levels (68.2-70.0\%) and lower total PUFA levels (1.8-7.3\%) in sheep heart. When compared to the fatty acid compositions of pork muscle tissues, the by-products had higher total SFA content and lower total PUFA contents (Alonso et al., 2011; Mas et al., 2011; Tikk et al., 2007). However, when compared to the SFA contents (36.68-50.36\%) and PUFA contents (2.65-3.87\%) in muscle tissues of Hanwoo, Angus and Japanese black cattle (Ba et al., 2013; Ladeira et al. 2014; Okumura et al., 2012), all pork by-products had similar total SFA levels but higher total PUFA levels.

The recommendations of Food and Agriculture Organization (FAO) and World Health Organization (WHO) for the dietary intakes of total fat and fatty acids for adult humans are total fat $20-35 \%$, less than 10\% SFA, $15-20 \%$ MUFA and 6-11\% PUFA (Burlingame et al., 2009). Therefore reducing the intake of SFAs and increasing the intake of PUFAs are strongly encouraged. Also, the recommendations for the PUFA/SFA ratio for the healthy diet as a whole should be 0.40 or higher, while the ratio of $n-6 / n-3$ fatty acids should be 4.0 or lower (Department of Health, 1994). According to the outcome of our analysis, the PUFA/SFA ratio in liver was twice higher than the recommended value of 0.4 ; also the PUFA/SFA ratio in heart, lung, stomach, small intestine, uterus and pancreas were above the recommended value of 0.4 . These values were almost equal to the values reported for pork meat (Tikk et al., 2007) and higher than the values reported for different beef muscles (Ba et al., 2013). By contrast, the $n-6 / n-3$ ratio in all by-products were above the recommended values of less than 4.0 in the present study. Similar to our results, Wood et al. (2003) also reported that pork contains a high content in $n-6$ fatty acids, which result in unfavorable $n-6 / n-3$ ratio. However, the $n-6 / n-3$ ratio in some pork by-products such as liver (8.75) was several times lower than the $n-6 / n-3$ ratio reported for pork meat (Alonso et al., 2011; Mas et al., 2011) and beef muscle (Brugiapaglia et al., 2014). This indicates that the $n-6 / n-3$ ratio in some by-products is more favorable than that in muscle tissues.

\section{Conclusion}

This paper studied the characteristics of pork by-products in terms of yield, physicochemical and nutritional compositions. On the basis of the results obtained, it could be concluded that the pork by-products especially liver, heart and pancreas, are rich sources of needed nutrients such as protein, EAAs, vitamins and mineral contents. Additionally, the fatty acid profile in these pork by-products was similar to that in muscle tissues. From our results, it can be said that the pork by-products are suitable for human consumption. Furthermore, the nutritional properties of these pork by-products could make it suitable for incorporation in comminuted meat products as well as processing them into other final products in order to increase economic benefits. This is the first study to characterize the yield, physicochemical and nutritional compositions of majority of edible pork by-products therefore the data of the present study provide not only the useful information for consumers but also the important databases for further investigations.

\section{Acknowlegements}

This work was supported by "Cooperative Research Program for Agriculture Science \& Technology Development (Project No. PJ90697402)" Rural Development Administration, Republic of Korea. We also would like to thank staffs at Animal Products and Processing Division for technical support. 


\section{References}

1. Agriculture and Horticulture Development Board. (2013) Country Report. Available from: http://www.bpex.org.uk/pricesfacts-figures/reports/documents/CountryReport_SouthKorea. pdf. Accessed June, 2013.

2. Alonso, V., Najes, L. M., Provincial, L., Guillen, E., Gil, M., Roncalés, P., and Beltran, J. A. (2012) Influence of dietary fat on pork eating quality. Meat Sci. 92, 366-373.

3. Anderson, B. A. (1988) Comparison and nutritional value of edible meat by-products. In: Edible Meat By-Products, Advance in Meat Research. Pearson, A. M. and Dutson, T. R. (eds) Elsevier Applied Science Publisher Ltd., London, UK, pp. 15-45.

4. AOAC (2000) Official methods of analysis of the AOAC 986.15 Multielement method. 17th ed, Arlington, Virginia, USA, pp. 1-8.

5. Aristoy, M. C. and Toldra, F. (2011) Essential amino acids. In: Handbook of Analysis of Edible Animal By-Products. Nollet, L. M. L. and Toldrá, F (eds) CRC Press, Boca Raton, FL, USA, pp. 123-135.

6. Ba, H. V., Park, K. M., Dashmaa, D., and Hwang, I. H. (2014) Effect of muscle type and vacuum chiller ageing period on the chemical compositions, meat quality, sensory attributes and volatile compounds of Korean native cattle beef. Anim. Sci. J. 85, 164-173.

7. Ba, H. V., Ryu, K. S., Nguyen, T. K. L., and Hwang, I. H. (2013) Influence of particular breed on meat quality parameters, sensory characteristics and volatile compounds. Food Sci. Biotechnol. 22, 651-658.

8. Benoist, B. (2001) Deficiency anemia: Reexamining the nature and magnitude of the public health problem. Introduction. Nutrition 131, 564S.

9. Bray, G. A., Paeratakul, S., and Popkin, B. M. (2004) Dietary fat and obesity: a review of animal, clinical and epidemiological studies. Physio. Behav. 83, 549-555.

10. Brugiapaglia, A., Lussiana, C., and Destefanis, G. (2014) Fatty acid profile and cholesterol content of beef at retail of Piemontese, Limousin and Friesian breeds. Meat Sci. 96, 568573.

11. Burlingame, B., Nishida, C., Uauy, R., and Weisell, R. (2009) Fats and fatty acids in human nutrition (Report of a joint FAO/ WHO Export Consultation, November, 2008). Ann. Nutr. Metab. 55, 1-380.

12. Channon, H. A., Kerr, M. G., and Walker, P. J. (2004) Effect of Duroc content, sex and ageing period on meat and eating quality attributes of pork loin. Meat Sci. 66, 881-888.

13. Department of Health. (1994) Nutritional aspects of cardiovascular disease (report on health and social subjects no 46). London UK: HMSO.

14. Devatkal, S., Mendiratta, S. K., Kondaiah, N., Sharma, M. C., and Anjaeyulu, A. S. R. (2004) Chysicochemical, functional and microbiological quality of buffalo liver. Meat Sci. 68, 7986.

15. Estevez, M., Ventanas, J., Cava, R., and Puolanne, E. (2005) Characterisation of a traditional Finnish liver sausage and dif- ferent types of Spanish liver pate: A comparative study. Meat Sci. 71, 657-669.

16. Florek, M., Litwińczuk, Z., Skałecki, P., Kędzierska-Matysek, M., and Grodzicki, T. (2012) Chemical composition and inherent properties of offal from calves maintained under two production systems. Meat Sci. 90, 402-409.

17. Folch, J., Lees, M., and Sloane-Stanley, G. H. (1957) A simple method for the isolation and purification of total lipid from animal tissue. J. Biol. Chem. 26, 497-507.

18. Garcia-Llatas, G., Alegria, A., Barbera R., and Farre, R. (2011) Minerals and trace elements. In: Handbook of Analysis of Edible Animal By-Products. Nollet, L. M. L. and Toldrá, F (eds) CRC Press, Boca Raton, FL, USA, pp. 183-203.

19. Hoffman, L. C., Laubscher, L. L., and Leisegang, K. (2013) Nutritional value of cooked offal derived from free-range rams reared in South Africa. Meat Sci. 93, 696-702.

20. Honikel, K. O. (2011) Composition and Calories. In: Handbook of Analysis of Edible Animal By-Products. Nollet, L. M. L. and Toldrá, F (eds) CRC Press, Boca Raton, FL, USA, pp. 105-121.

21. Honikel, K. O. and Wellhauser, R. (1993) Zusammensetzung verbrauchergerecht zugeschnittener schweinefleischteilstiicke. Fleischwirtschaft. 73, 863-866.

22. Jiménez-Colmenero, F., Ventanas, J., and Toldrá, F. (2010) Nutritional composition of dry cured ham and its role in a healthy diet. Meat Sci. 84, 585-593.

23. Keran, H., Salkic, A., Odobasic, A., Jasic, M., Ahmetovic, N., and Sestan, I. (2009) The importance of determination of some physical - chemical properties of Wheat and Flour. Agric. Conspec. Sci. 74, 197-200.

24. Kim, Y. B., Jeon, K. H., Lee, N. H., and Lee, H. J. (2008) An analysis of the nutritional quality of spreadable liver product. Korean J. Food Sci. An. 28, 21-26.

25. Kim, Y. N. (2011) Vitamins. In: Handbook of Analysis of Edible Animal By-Products. Nollet, L. M. L. and Toldrá, F (eds) CRC Press, Boca Raton, FL, USA, pp. 161-182.

26. Kurt, S. and Zorba, O. (2007) Emulsion characteristics of beef and sheep offal. J. Muscle Foods 18, 129-142.

27. Ladeira, M. M., Santarosa, L. C., Chizzotti, M. L., Ramos, E. M., Machado-Neto, O. R., and Oliveira, D. M. (2014) Fatty acid profile, color and lipid oxidation of meat from young bulls fed ground soybean or rumen protected fat with or without monensin. Meat Sci. 96, 597-605.

28. Lebiedzinska, A. and Szefer, P. (2006) Vitamins B in grain and cereal-grain food, soy-products and seeds. Food Chem. 95, 116-122.

29. Marustic, N., Petrovic, M., Vidacek, S., Petrak, T., and Medic, H. (2011) Characterization of traditional Istrian dry-cured ham by means of physical and chemical analyses and volatile compounds. Meat Sci. 88, 786-790.

30. Mas, G., Llavall, M., Coll, D., Roca, R., Díaz, I., Oliver, M. A., Gispert, M., and Realini, C. E. (2011) Effect of an elevated monounsaturated fat diet on pork carcass and meat quality traits and tissue fatty acid composition from York-crossed barrows and gilts. Meat Sci. 89, 419-425.

31. Mestre-Prates, J. A., Alfaia, C. M., Alves, S. P., and Bran- 
quinho, R. J. (2011) Fatty acids. In: Handbook of Analysis of Edible Animal By-Products. Nollet, L. M. L. and Toldrá, F (eds) CRC Press, Boca Raton, FL, USA, pp. 137-155.

32. Moon, S. S., Yang, H. S., Park, G. B., and Joo, S. T. (2006) The relationship of physiological maturity and marbling judged according to Korean grading system to meat quality traits of Hanwoo beef females. Meat Sci. 74, 516-521.

33. Morrison, W. R. and Smith, L. M. (1964) Preparation of fatty acid methyl esters and dimethylacetals from lipids with boron trifluoride-methanol. J. Lipid Res. 5, 600-608.

34. Ngapo, T., Riendeau, M., Laberge, C., Leblanc, D., and Fortin, J. (2012) "Chilled" pork-Part I: sensory and physicochemical quality. Meat Sci. 92, 330-337.

35. Nollet, L. M. L. and Toldrá, F. (2011) Introduction of Offal meat: Definitions, regions, cultures, generalities. In: Handbook of Analysis of Edible Animal By-Products. Nollet, L. M. L. and Toldrá, F (eds) CRC Press, Boca Raton, FL, USA, pp. 3-11.

36. Ockerman, H. W. and Basu, L. (2004) By-products. In: Encyclopedia of meat sciences. Jensen, W. K., Devine, C., and Dikeman, M (eds) Elsevier Academic Press, Amsterdam, London, pp. 104-112.

37. Okumura, T., Saito, K., Sowa, T., Sakuma, H., Ohhashi, F., Tameoka, N., Hirayama, M., Nakayama, S., et al. (2012) Changes in beef sensory traits as somatic-cell-cloned Japanese black steers increased in age from 20 to 30 months. Meat Sci. 90, 159-163.

38. Pereira, P. M. C. C. and Vicente, A. F. R. B. (2013) Meat nut- ritional composition and nutritive role in the human diet: Review. Meat Sci. 93, 586-592.

39. Santos, E. M., Fernández, C. G., Jaime, I., and Rovira, J. (2003) Physicochemical and sensory characterization of Morcilla de Burgos, a traditional Spanish blood sausage. Meat Sci. 65, 893-898.

40. SAS Institute, Inc. (2007) SAS User's Guide. Release. 9.1.3. Statistical Analysis System Institute. Cary, NC, USA.

41. Spackma, D. H., Stein, W. H., and Moore, S. (1958) Automatic recording apparatus for use in chromatography of amino acids. Anal Chem. 30, 1190-1206.

42. Tapiero, H. and Tew, K. D. (2003) Trace elements in human physiology and pathology: zinc and metallothioneins. Biomed. Pharmacother. 57, 399-411.

43. Tikk, K., Tikk, M., Aaslyng, M. D., Karlsson, A. H., Lindahl, G., and Andersen, H. J. (2007) Significance of fat supplemented diets on pork quality Connections between specific fatty acids and sensory attributes of pork. Meat Sci. 77, 275-286.

44. Toldra, F., Aristoy, M. C., Mora, L., and Reig, M. (2012) Innovations in value-addition of edible meat by-products. Meat Sci. 92, 290-296.

45. Wood, J. D., Richardson, R. I., Nute, G. R., Fisher, A. V., Campo, M. M., and Kasapidou, E. (2003) Effects of fatty acids on meat quality: A review. Meat Sci. 66, 21-32.

46. Wu, G. (2010) Functional amino acids in growth, reproduction, and health. Advances in Nutrition 1, 31-37.

(Received 2014.2.27/Revised 2014.4.10/Accepted 2014.4.15) 